\title{
Host-Range Dynamics of Cochliobolus lunatus: From a Biocontrol Agent to a Severe Environmental Threat
}

\section{Bengyella Louis, ${ }^{1,2,3}$ Sayanika Devi Waikhom, ${ }^{1}$ Pranab Roy, ${ }^{4}$ Pardeep Kumar Bhardwaj, ${ }^{5}$ Chandradev K. Sharma, ${ }^{1}$ Mohendro Wakambam Singh, ${ }^{1}$ and Narayan Chandra Talukdar ${ }^{1}$}

\author{
${ }^{1}$ Institute of Bioresources and Sustainable Development (IBSD), Takyelpat, Imphal, Manipur 795001, India \\ ${ }^{2}$ Department of Biotechnology, The University of Burdwan, Golapbag More, West Bengal 713104, India \\ ${ }^{3}$ Department of Biochemistry, University of Yaoundé I, BP 812, Yaoundé, Cameroon \\ ${ }^{4}$ Department of Biotechnology, Haldia Institute of Technology, Haldia, West Bengal 721657, India \\ ${ }^{5}$ Regional Centre of Institute of Bioresources and Sustainable Development (RCIBSD), Gangtok, Sikkim 737102, India
}

Correspondence should be addressed to Bengyella Louis; bengyellalouis@gmail.com

and Narayan Chandra Talukdar; nctalukdar@yahoo.com

Received 22 February 2014; Revised 28 April 2014; Accepted 13 May 2014; Published 2 June 2014

Academic Editor: Fengjie Sun

Copyright (C) 2014 Bengyella Louis et al. This is an open access article distributed under the Creative Commons Attribution License, which permits unrestricted use, distribution, and reproduction in any medium, provided the original work is properly cited.

\begin{abstract}
We undertook an investigation to advance understanding of the host-range dynamics and biocontrol implications of Cochliobolus lunatus in the past decade. Potato (Solanum tuberosum L) farms were routinely surveyed for brown-to-black leaf spot disease caused by C. lunatus. A biphasic gene data set was assembled and databases were mined for reported hosts of C. lunatus in the last decade. The placement of five virulent strains of $C$. lunatus causing foliar necrosis of potato was studied with microscopic and phylogenetic tools. Analysis of morphology showed intraspecific variations in stromatic tissues among the virulent strains causing foliar necrosis of potato. A maximum likelihood inference based on GPDH locus separated C. lunatus strains into subclusters and revealed the emergence of unclustered strains. The evolving nutritional requirement of $C$. lunatus in the last decade is exhibited by the invasion of vertebrates, invertebrates, dicots, and monocots. Our results contribute towards a better understanding of the host-range dynamics of $C$. lunatus and provide useful implications on the threat posed to the environment when C. lunatus is used as a mycoherbicide.
\end{abstract}

\section{Introduction}

Race specific Cochliobolus species have caused plant disease disaster such as the southern leaf corn blight epidemic of 1970s in the United States of America [1], northern leaf corn blight (Exserohilum turcicum) and corn head smut (Sporisorium reilianum) in northern China in the 1990s [2,3], and the Great Bengal rice famine of India in 1940s [4, 5]. In the Great Bengal rice famine, more than 2 million people starved to death due to reduction in rice yield of about 40 to 90\% [5]. Cochliobolus species often cause diseases to several plant families including Alliaceae, Anacardiaceae, Araceae, Euphorbiaceae, Fabaceae, Malvaceae, Rutaceae, Zingiberaceae and Solanaceae [6].

Cochliobolus lunatus [7] and related species are extensively used as mycoherbicides for controlling weeds in paddies [8-13]. The host-range of C. lunatus includes plant species, namely, Cynodon sp., Oryza sp., Pennisetum sp., Saccharum sp., Sorghum sp., Triticum sp., and Zea sp. [14]. Geographically, C. lunatus was suggested to be located mainly in Australia, Brazil, Guinea, India, Cameroon, Columbia, Ecuador, Fiji, Gambia, Guadalcanal, Malaysia, Nigeria, Pakistan, Papua New Guinea, Sierra Leone, Sri Lanka, Sudan, Tanzania, Thailand, and USA [14] but not in Europe (http://www.tifton.uga.edu/fat/disfunt2.htm). The proposed geographical circumscription and putative hosts of $C$. lunatus have not been updated.

C. lunatus has emerged in the last decade as a virulent and destructive pathogen $[15,16]$. Remarkably, C. lunatus successfully thrives on important crops such as rice (Oryza sativa L.), wheat (Triticum aestivum), cassava (Manihot esculenta), sorghum (Sorghum bicolor), Hymenaches species, 
strawberry (Fragaria $\times$ ananassa), Amaranthus species, and potato [16-20]. Decades after Sivanesan's [14] pioneering study, is C. lunatus solely endemic to the outlined geographical locations? If no, has $C$. lunatus gained hosts and new geographical zones in the last decade? The aims of this study were (1) to determine the interrelatedness of 5 virulent strains of C. lunatus causing foliar necrosis of potato using morphological descriptors coupled with phylogenetic tools and (2) to establish the current host-range diversity of $C$. lunatus in the last decade.

\section{Materials and Methods}

2.1. Study Area and Sampling. Routine survey was performed in potato plantations of Burdwan District $\left(23^{\circ} 14^{\prime} \mathrm{N}, 87^{\circ} 51^{\prime} \mathrm{E}\right.$, altitude $150 \mathrm{~m}, 102.1 \mathrm{~km}$ from Kolkata), West Bengal, India, during the winter months of December to March of 2010, 2011, and 2012. Mainly potato cv. Kufri Jyoti is farmed in Burdwan District. The area receives an average annual rainfall of $1173-1442 \mathrm{~mm}$ and temperature of $10-20^{\circ} \mathrm{C}$ during potato farming season. Potato plants showing brown-to-black leaf spot disease previously described [20] were used. Brown-toblack leaf spots were excised and treated with $2 \% \mathrm{NaClO}$ solution for $2 \mathrm{~min}$ and rinsed in sterile water with three changes. The leaf pieces were aseptically plated on V8 agar medium (HiMedia, Mumbai, India) and incubated at $25^{\circ} \mathrm{C}$ in dark. Developed colonies after 7 days were morphologically identified based on standard monograph taxonomic keys [7].

2.2. Host-Range Diversity. The genomic DNA was isolated from fungal isolates grown in potato dextrose broth (PDB) (HiMedia, Mumbai, India). Approximately $100 \mathrm{mg}$ of mycelia mat was disrupted in the presence of TRIreagent (Sigma, St. Louis, MO, USA) using mortar and pestle containing $2 \mathrm{mg} / \mathrm{mL}$ proteinase K (Merck, Bangalore, India) following the manufacturer instructions. The quality and quantity of the DNA were determined using a $1 \%$ agarose gel electrophoresis and a nanodrop spectrophotometer (BioSpec-nano, Shimadzu, Japan), respectively. For molecular identification, the partial sequence of 5.8S rDNA, complete internal transcribed spacer 2 region (ITS2), and partial 28S rDNA region were amplified as previously described [23]. To distinguish the strains, we designed specific primers (forward: $5^{\prime}$-cgatatgcggcatatgca- $3^{\prime}$; reverse: $5^{\prime}$ acctacgcattgcggaa- $3^{\prime}$ ) for glyceraldehyde-3-phosphate dehydrogenase (GPDH) gene using C. lunatus (GenBank accession number Gb X58718) sequence. Amplification of GPDH was performed as follows. The PCR mix contained $11 \mathrm{ng}$ genomic DNA, $5 \mu \mathrm{L}$ Green GoTaq reaction buffer (Promega, Madison, WI, USA), $0.2 \mathrm{mM}$ each of deoxyribonucleoside triphosphate (dNTP), $0.2 \mu \mathrm{M}$ of each primer, and $1.1 \mathrm{U}$ of GoTaq DNA polymerase in a total reaction volume of $25 \mu \mathrm{L}$ in triplicates (PCR conditions: $5 \mathrm{~min}$ at $95^{\circ} \mathrm{C}, 35$ cycles of $1 \mathrm{~min}$ at $94^{\circ} \mathrm{C}$, $1 \mathrm{~min}$ annealing at $53^{\circ} \mathrm{C}, 2 \mathrm{~min}$ for extension at $72^{\circ} \mathrm{C}$, and a final 5 min extension at $72^{\circ} \mathrm{C}$ ). The quality of the amplicon was checked by performing agarose gel electrophoresis. The PCR products were purified and sequenced. Sequences were assigned to molecular species based on $98-100 \%$ sequence similarity threshold in the GenBank with the following accession numbers: JX512810, JX512809, JX907827, JX477595, and JX907828, respectively, for rDNA. GPDH sequences have been submitted in DNA Data Bank of Japan (DDBJ) as accessions AB859034, AB859035, AB859036, AB859037, and AB859038, respectively.

Using GenBank BLAST search tool, a studied set of rDNA sequences deposited in the last decade was collected based on the information associated with the sequences such as GC content, length (>250 bp), and geographic origin of host. Importantly, records with $100 \%$ sequence similarity from the same host and geographical coordinates were removed. Unique sequence sets were screened using ElimDupes (available at http://hcv.lanl.gov/content/sequence/ELIMDUPES/elimdupes.html). Sequence alignment was performed using Muscle program [24]. Best substitution model parameters were determined based on Akaike information criterion, corrected (AICc) and Bayesian information criterion (BIC). The evolutionary history was inferred using the maximum likelihood (ML) method, and rooting was performed automatically by saving the generated ML tree in standard Newick format and all the analysis were performed in MEGA 6.06 (updated v. 6140226) software [25]. The strength of the internal branches of the ML tree was statistically tested by performing 1000 bootstrap replications.

\section{Results and Discussion}

3.1. Identification of C. lunatus Strains Causing Foliar Necrosis of Potato. Basically, most Cochliobolus species have curved conidia, a broad rounded apex cell, a distinct swollen central cell, a tapering to narrowly round base cell, and 4-5 distinct septa. The five strains of Cochliobolus causing brown-toblack leaf spot disease of potato produced varied colonies and conidia (Figure 1) similar to previous studies [6,7]. The isolates visibly produced different growth patterns (Figure 1). In one isolate Btl26IBSD (DDBJ accession AB859034), brown to whitish mycelium, reddish brown medium, and canoe five-celled conidia without stromatic tissues were observed (Figure 1(a)). In C. lunatus, the stromata are oval or ellipsoidal, 10 to $40 \mu \mathrm{m}$ in diameter, and located beneath the ascomata. Another isolate Btl27IBSD (DDBJ accession AB859035) produced greyish-brown mycelium and cylindrical clavated fived-celled conidia void of stromatic tissue (Figure 1(b)). Isolate Btl28IBSD (DDBJ accession AB859036) profusely produced yellowish pigmented five-celled conidia, with stromatic tissue, variable shapes, and end at one cell with a thin hilium (Figure 1(c)). Isolates Btl29IBSD (DDBJ accession AB859037) and Btl30IBSD (DDBJ accession AB859038) produced greyish-brown cottony mycelium (Figures $1(\mathrm{~d})$ and 1(e)). Noteworthy, isolate Btl30IBSD profusely produced dark pigments, and with each cell of the conidia bearing a distinctive oval stromata of different sizes. The exact role of stromata in pathogenicity is not known. The stromata are enclosed by a ring of melanin-like pigment, may play a role in preventing desiccation of the conidia, conserved the gene-pool, and ensure survival under adverse conditions. 


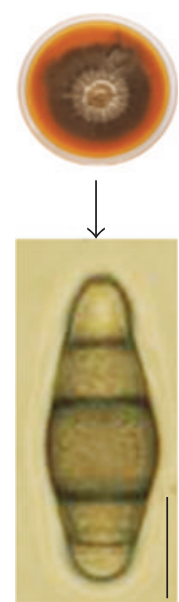

(a)

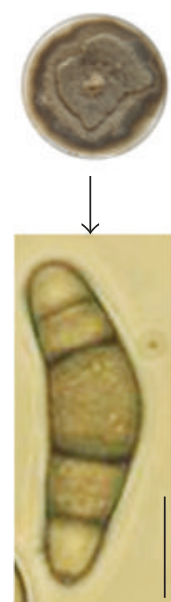

(b)

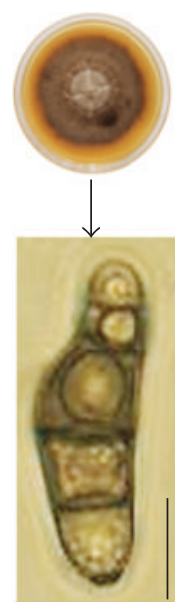

(c)

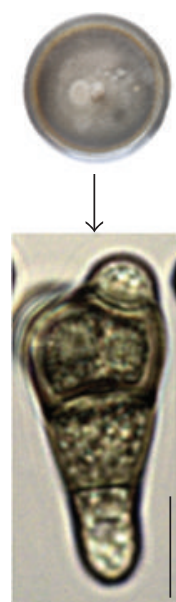

(d)

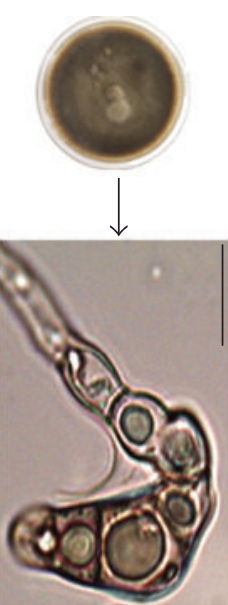

(e)

FIGURE 1: Light microscopic images showing morphological variations of five strains of Cochliobolus lunatus causing brown-to-black leaf spot disease of potato. (a) Strain Btl26IBSD (DDBJ accession AB859034) with no stromata, (b) strain Btl27IBSD (DDBJ accession AB859035) with no stromata, (c) Btl28IBSD (DDBJ accession AB859036) having stromatic tissue, (d) strain Btl29IBSD (DDBJ accession AB859037) having stromatic tissue, and (e) strain Btl30IBSD (DDBJ accession AB859038) having stromatic tissue. Images were acquired with Olympus DP70 camera (Olympus BX61, USA) at 1000X magnification and scale bars represent $10 \mu \mathrm{m}$.

As shown (Figure 1), morphological characters revealed significant intraspecific variations.

Taxonomic circumscription of Cochliobolus has undergone countless modifications in the last five decades caused by overlapping morphological characters $[6,7,14,15]$. Furthermore, generic concepts delimiting Bipolaris, Cochliobolus, and Pseudocochliobolus are confused [6,7]. Thus, ITS region of the ribosomal RNA operon was used to accurately determine the taxonomic placement of the fungi. Based on rDNA locus, we confirmed that the five fungi causing brownto-black leaf spot disease of potato (Figures 2(a) and 2(b)) were $C$. lunatus. In the ML tree, the five strains of $C$. lunatus causing brown-to-black leaf spot disease of potato clustered (Figure 2(c), (I)), closely related to other GenBank type isolates (Figure 2(c), (II)) and distant from other Cochliobolus species. The nucleotide frequencies were $\mathrm{A}=25.00 \%, \mathrm{~T} / \mathrm{U}=$ $25.00 \%, C=25.00 \%$, and $\mathrm{G}=25.00 \%$. The transitiontransversion bias estimated by K2 + I substitution model [21] was 2.41. The overall rate of heterogeneity between taxa was 0.01 . As expected, low level single nucleotide polymorphism (SNP, 5.4\%) was observed out of a total of 1188 sites at the rDNA locus. The five strains causing foliar necrosis of potato were weakly supported with bootstrap values $\leq 61 \%$. As previously reported, rDNA locus do not often provide ample resolution that can allow differentiation of cryptic taxa such as Cochliobolus $[6,15]$.

The low bootstrap support $(\leq 61 \%)$ generated in rDNA ML tree (Figure 2, (I)) made it difficult to determine whether the five strains of C. lunatus causing brown-to-black spot disease of potato in Burdwan Destrict were identical. It could be that all the strains originated from a common source but colonized in different places following dispersion. This is because $C$. lunatus abundantly produced conidia that can easily be disseminated by air to distant places. To check if the five isolates were identical or not, we used glyceraldehyde 3-phosphate dehydrogenase (GPDH) locus which had been shown to be effective in resolving Cochliobolus species in phylogenetic inference $[6,15]$. Partial GPDH locus (Figure 3(a)) was sequenced, as this is one of the house-keeping genes, taken as reference in yeast and fungal systems. Based on sequence alignment for GPDH locus, a total of 340 SNPs out of 708 sites and 325 sites without polymorphism (45.9\%) were found. Based on TN93 + G + I substitution model [22], the rate of base transition-transversion was 4.96 and the nucleotide frequencies were $\mathrm{A}=23.73 \%, \mathrm{~T} / \mathrm{U}=18.55 \%, \mathrm{C}=$ $33.52 \%$, and $\mathrm{G}=24.20 \%$ and the overall heterogeneity among taxa was 0.316 . The ML tree based on GPDH locus discriminated the five strains of $C$. lunatus causing foliar necrosis of potato with strong bootstrap support $\geq 81 \%$ (Figure 3(b), (IV)). The overall mean evolutionary distance of 0.03 was observed between the five strains causing foliar necrosis of potato (Figure 3(b), (IV)) relative to other C. lunatus type isolates (Figure 3(b), (I), (II), and (III)).

Importantly, because the five strains of $C$. lunatus clustered based on GPDH locus (Figures 2(b) and 3(b)), this indicated they were closely related as also revealed on the basis of morphological descriptors (Figure 1). Additionally, bootstrap values were $<100 \%$ for internal branches within the subcluster I, Figure 3(b). This indicated that the five strains which caused foliar necrosis of potato were different. Although the five C. lunatus strains might have adapted in potato for their nutritional requirements in the same geoclimatic zone, it was not possible to determine their origin. Importantly, it is shown that pathogenic fungi are capable of adapting to the genetic background of their host, thus forming new physiological and virulent races [26]. This is generally a slow progressive process determined mainly by the degree of the pathogen-host specific interactions [27]. 


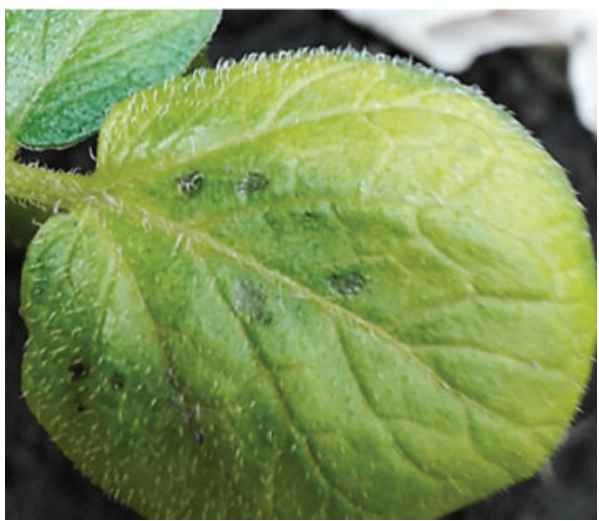

(a)

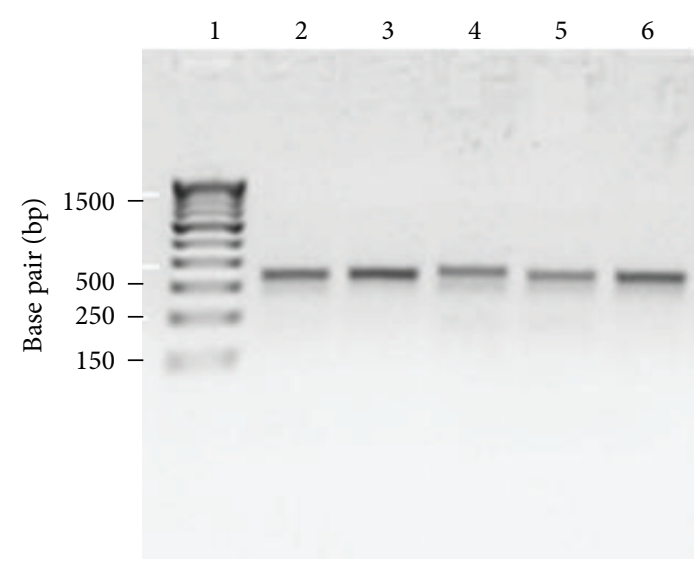

(b)

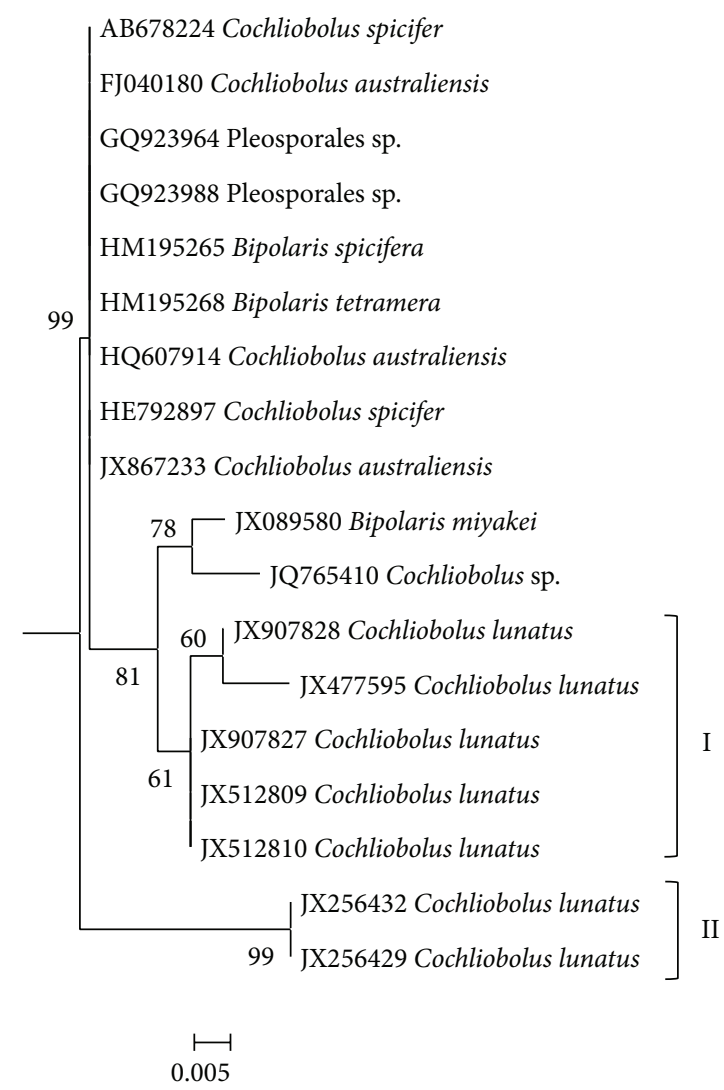

(c)

Figure 2: (a) Archetypal brown-to-black leaf spot disease caused by Cochliobolus lunatus on potato cv. Kufri Jyoti as previously validated by Koch's postulates [20]. (b) Agarose gel electrophoresis for PCR products (475 bp) from rDNA locus of Cochliobolus lunatus strains separated on a 2.5\% agarose gel. Lane-1 DNA ladder and lane-2, -3, -4, -5, and -6 are Cochliobolus lunatus strains with GenBank accessions numbers JX512810, JX512809, JX907827, JX477595, and JX907828, respectively. (c) Molecular phylogenetic analysis by maximum likelihood method based on the $\mathrm{K} 2+\mathrm{G}$ substitution model [21]; AIC is 871.49; BIC is 1093.89; the highest log likelihood is -429.87 and bootstrap values $\geq 50 \%$ from 1000 iterations are shown. Subcluster I contain strains of Cochliobolus lunatus which causes foliar necrosis of potato.

Collectively, because of some phenotypical variations such as colonies growth pattern, presence or absence of stromatic tissues, colours of conidia and colonies (Figure 1), and strong bootstrap support $(>81 \%)$ for clustered and unclustered strains (Figure 3(b), (I), (II), and (III)), C. lunatus strains have evolved divergently.
3.2. Host-Range Diversity. Herein, the term host-range diversity described the group of different hosts on which $C$. lunatus successfully thrived on such as monocots, dicots, invertebrates, and vertebrates. The known hosts of C. lunatus presented by Sivanesan [14] in 1987 are plant species, namely, Cynodon sp., Oryza sp., Pennisetum sp., Saccharum sp., 


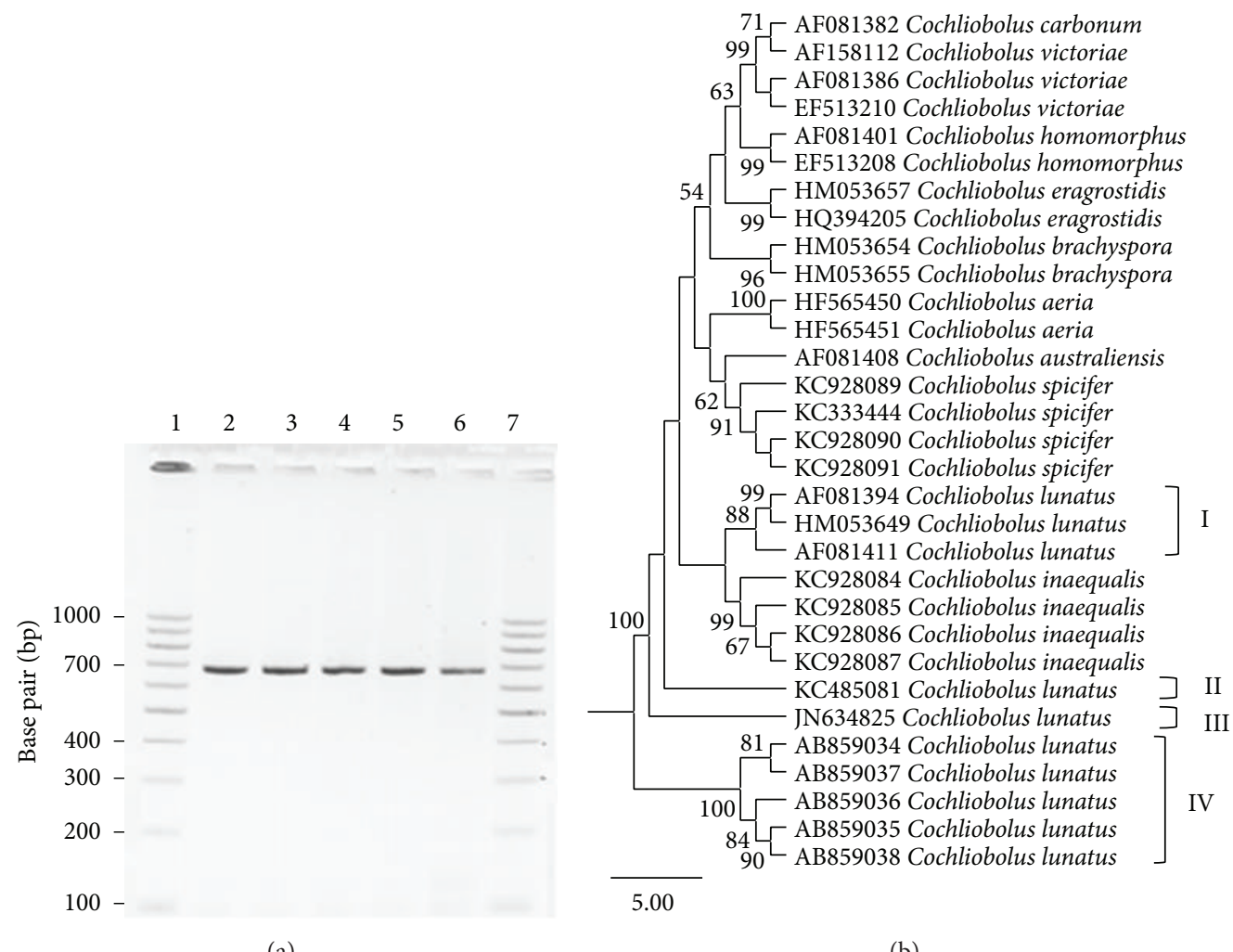

(a)

(b)

FIgURE 3: (a) Agarose gel electrophoresis for PCR products $(680 \mathrm{bp})$ from GPDH locus of Cochliobolus lunatus strains separated on a 2.5\% agarose gel. Lane-1 and-7 DNA ladder and lane-2, -3, -4, -5, and -6 are Cochliobolus lunatus strains with DDBJ accessions AB859034, AB859035, AB859036, AB859037, and AB859038, respectively. (b) Molecular phylogenetic analysis by maximum likelihood method based on the TN93 + G + I substitution model [22]; AIC is 2974.83; BIC is 3449.49; the highest log likelihood is -1494.28 and bootstrap values $\geq 50 \%$ from 1000 iterations are shown. Subcluster (IV) contains strains of Cochliobolus lunatus which causes foliar necrosis of potato.

Sorghum sp., Triticum sp., and Zea sp. There was no up-todate account on the new host gained by C. lunatus since Sivanesan [14] account. By exploring the public repositories, we found that $C$. lunatus have gained hosts within host groups such as monocots, dicots, vertebrates, and invertebrates in the last decade (Table 1). New hosts gained in the last decade are Homo sapiens, Musa acuminata, Jatropha curcas, Echinochloa sp., Arecales sp., Cyperaceae sp., Panicum sp., Setaria italic, Solanum tuberosum L., Glycine max L., Nelumbo nucifera, Eugenia jambolana, Actinidia deliciosa, Actinidia sp., Trachymyrmex septentrionalis, and Cyphomyrmex wheeleri (Table 1), geographically distributed across Africa, Asia, North America, South America, and Europe. It is worth noting that Europe was not included in Sivanesan [14] report by 1987 (http://www.tifton.uga.edu/fat/disfunt2.htm). Other C. lunatus new hosts reported $[19,28-40]$ in the last decade without nucleotide sequence information are depicted (Table 2).

This study seeks to advance insights on the host-range diversity allowing the dynamic movement of $C$. lunatus observed in the last decade (Tables 1 and 2). From Table 1, it is understood that C. lunatus exploit two kingdoms, notably plant and animal, switching among monocots, dicots, invertebrates, and vertebrates. The paradigm-shift from a plant colonizer sensu stricto to a vertebrate and invertebrate invader (Tables 1 and 2) indicates that $C$. lunatus have acquired special strategies to switch hosts. The question arises as to why $C$. lunatus display extensive host-range diversity in a given biota.

Although studies have shed light on specific aspects of C. lunatus pathogenicity such as induce-virulence variations on maize crop [41], virulence differentiation on maize crop [42], secretome weaponries on potato crop [43], and heatdependent virulence on Lolium spp. [44], the nutritional evolution of C. lunatus is unresolved. Intriguingly, host shifting dynamics is not well understood and it has been argued that (1) close proximity to host is prerequisite for pathogens to jump from a natural host to a new host [45], (2) the future host must act as the substrate [15, 45], and (3) compatible factors promoting infection must be present $[45,46]$. Importantly, most host-switching pathogens selfprotect themselves by producing high level pigment such as melanin to deal with the host defense [42, 47, 48]. Additionally, C. lunatus profusely produced melanized colonizing hyphae during invasion in potato [43] and non-host-specific toxin such as methyl-5-[hydroxymethylfuran-2-carboxylate] in maize [49], to suppress the host defense.

Nonetheless, the above-mentioned factors seem more likely to be limited in explaining how $C$. lunatus gain access to hosts and not how $C$. lunatus spreads in a given biota 
TABLE 1: Information associated with rDNA locus of C. lunatus deposited in the GenBank, DDBJ, and EMBL in the last decade on different host groups such as invertebrates, vertebrates, monocots, and dicots from Asia, Africa, South America, North America, and Europe.

\begin{tabular}{|c|c|c|c|c|}
\hline Accessions & Host & Host group & Geographic origin & Date of report \\
\hline EU828350 & Allelopathic rice (leaf) & \multirow{18}{*}{ Monocots } & China (Fujian) & 16-Jul-2008 \\
\hline GQ179977 & Musa acuminata & & China & 27-Jun-2009 \\
\hline GQ328852 & Zea sp. (seed) & & USA (Peoria) & 25-Jun-2009 \\
\hline JF798505 & Jatropha curcas & & Mexico & 16-Feb-2012 \\
\hline JX256435 & Oryza sp. (leaf) & & Thailand & 10-Sep-2012 \\
\hline HQ248192 & Arecales (Oil palm, leaf) & & Colombia & 31-Oct-2010 \\
\hline AF163082 & Oryza sp. & & China (Hong Kong) & 27-Jul-2000 \\
\hline GQ328851 & Zea sp. (seed) & & US (Peoria) & 05-Aug-2009 \\
\hline FJ040177 & Oryza sp. (grains) & & China (Zhejiang) & 20-Sep-2008 \\
\hline EF189917 & Echinochloa sp. (leaf) & & China (Zhejiang) & 22-Jan-2007 \\
\hline JN207244 & Cyperaceae sp. (Sedges, leaf) & & Venezuela (Northwest) & 22-Jun-2012 \\
\hline JX256436 & Echinochloa sp. (leaf) & & Thailand & 10-Sep-2012 \\
\hline$J X 256432$ & Panicum sp. & & Thailand & 10-Sep-2012 \\
\hline JX256444 & Panicum sp. & & Solomon Island & 10-Sep-2012 \\
\hline HQ130484 & Panicum virgatum (switchgrass) & & USA (Tennessee) & 29-Aug-2012 \\
\hline JN943425 & Echinochloa sp. & & Japan (Kochi) & 21-Dec-2011 \\
\hline JN943426 & Setaria italica (leaf) & & Japan (Kagoshima) & 21-Dec-2011 \\
\hline JN943424 & Setaria italica (leaf) & & Japan & 21-Dec-2011 \\
\hline JX512810* & S. tuberosum L. (leaf) & \multirow{11}{*}{ Dicots } & India (Burdwan) & 20-Aug-2012 \\
\hline JX512809* & S. tuberosum L. (leaf) & & India (Burdwan) & 20-Aug-2012 \\
\hline JX907827* & S. tuberosum L. (leaf) & & India (Burdwan) & 09-Sep-2012 \\
\hline JQ936200 & Glycine max L. (leaf) & & Brazil & 16-Apr-2012 \\
\hline JX477595* & S. tuberosum L. (leaf) & & India (Burdwan) & 12-Aug-2012 \\
\hline JX907828* & S. tuberosum L. (leaf) & & India (Burdwan) & 09-Sep-2012 \\
\hline JQ701798 & Nelumbo nucifera (leaf) & & China (Jiangxi) & 01-Jul-2012 \\
\hline JQ765410 & Ipomoea carnea (leaf) & & India & 03-Jul-2012 \\
\hline KC937052 & S. tuberosum L. (leaf) & & India & 12-Aug-2013 \\
\hline KF031026 & Eugenia jambolana & & India & 11-May-13 \\
\hline JX256445 & Actinidia deliciosa & & Solomon Island & 10-Sep-2012 \\
\hline JF819163 & Actiniaria sp. & \multirow{6}{*}{ Invertebrates } & China (Yushan) & 19-Apr-2011 \\
\hline JQ717321 & Corales & & China (Guangdong) & 13-Aug-012 \\
\hline HQ608077 & Trachymyrmex septentrionalis & & USA (Texas) & 15-Nov-2011 \\
\hline HQ608020 & Cyphomyrmex wheeleri & & Brazil & 15-Nov-2011 \\
\hline JQ388928 & Marine sponge & & Panama & 01-Jun-2012 \\
\hline HQ607975 & Cyphomyrmex wheeleri & & USA (Texas) & 15-Nov-2011 \\
\hline JX256429 & Human lungs biopsy & \multirow{3}{*}{ Vertebrate } & USA & 10-Sep-2012 \\
\hline HE861835 & Human nasal nostrils & & Spain & 23-Jul-2013 \\
\hline KC288118 & Human subcutaneous tissue & & Brazil & 21-Nov-2012 \\
\hline EU759980 & Plant & \multirow{5}{*}{ Unknown } & Egypt & 25-Jun-2008 \\
\hline HQ174562 & Unknown & & China (Shandong) & 22-Feb-2011 \\
\hline JN943422 & Unknown & & United kingdom & 17-Apr-2012 \\
\hline FJ792584 & Medicinal plants & & China (Jiangsu) & 30-Mar-2009 \\
\hline AF071339 & Unknown & & Canada & 10-Jun-1998 \\
\hline JX077054 & Wetland sediment & Soil & China (Zhejiang) & 17-Jul-2012 \\
\hline
\end{tabular}

${ }^{*}$ Accessions corresponding to isolates causing brown-to-black leaf spot disease of potato reported in this study. 
TABLE 2: New Cochliobolus lunatus hosts reported in the last decade without sequence information.

\begin{tabular}{lccc}
\hline Host origin & Geographic origin & Year of report & Reference \\
\hline Dioscorea sp. & Nigeria & 2005 & Amusa et al. [28] \\
Chrysalidocarpus lutescens & New Zealand & 2006 & Braithwaite et al. [29] \\
Saccharum officinarum & Japan & 2008 & Nishi et al. [30] \\
Passiflora edulis f. flavicarpa Deg. & Philippines & 2009 & Marvin and Naomi [31] \\
Pennisetum typhoides & Pakistan & unknown & Azhar et al. [32] \\
Fragaria $\times$ ananassa Dutch (Strawberry) & India & 2010 & Verma et al. [19] \\
Grewia optiva & India & 2011 & Cvetomir [33] \\
Basella rubra & India & 2011 & Pandey et al. [34] \\
Mimusops elengi Linn & India & 2011 & Selima et al. [35] \\
Amaranthus spinosus & India & 2011 & Sharma et al. [36] \\
Vicia faba & Egypt & 2012 & Saleem et al. [37] \\
Allium sativum L. & India & 2013 & Ghangaonkar [38] \\
Lake water (Fishes) & India & 2013 & Pratibha et al. [39] \\
Clerodendrum indicum & India & 2013 & Mukherjee et al. [40] \\
\hline
\end{tabular}

and prevails as an environmental hazard. C. lunatus had extensively been used as mycoherbicide formulations in the past decade [8-13]. Remarkably, Zhang et al. [12] fused the protoplast of Helminthosporium gramineum and C. lunatus, to generate a strain with high potential to produce conidia, phytotoxin ophiobolin, and improved potential to control rice weed. Introduction of genetically manipulated strains and unmodified strains of C. lunatus could have hazardous implications to the environment. This is because, in some cases, C. lunatus failed to control the targeted weeds but caused severe damages in economically important crops in the same biota. For instance, C. lunatus isolated from barnyardgrass and used as mycoherbicide failed to control competitive weeds in rice fields but severely damaged bean varieties [8]. Nevertheless, the effectiveness of a biocontrol in the fields depends on the environmental conditions of a given biota, especially humidity and temperature [10]. C. lunatus exhibits a temperature-dependent virulence [43, 44] and its introduction into the environment without a precise prediction of the geoclimatic conditions, that is, humidity and temperature, can prove harmful; consequently, it disequilibrates the interaction dynamics of the organisms dwelling in the same biota.

Owing to the divergence in evolution (Figure 1, (I) and (II)) and the emergence of unclustered strains (Figure 2, (I) and (II)), it is clear that strains of C. lunatus have coevolved with their different hosts translated by their different placement in ML tree inference and speciation in their nutritional requirements (Tables 1 and 2). In keeping with the results of the evolutionary disparity, the global control of C. lunatus diseases would require tremendous exertion. This is because in an intermixed network of host-groups, C. lunatus strains from different hosts, genetically distant ((IV) versus (I), (II), and (III), Figure 2(b)) and found in the same geographic zone, would readily invade putative hosts regardless of their temporal host-groups. For instance in the last three years in India, C. lunatus have invaded strawberry [19], Mimusops elengi [37], Amaranthus spinosus [36],
Grewia optiva [33], Clerodendrum indicum [40], and potato $[20,48]$. Noteworthy, these hosts were spatially and temporally distant. With this illustration, it is clear that the host-pathogen proximity hypothesis and host relatedness hypothesis, where a given pathogen switches to new species closely related to the original host, might all apply for $C$. lunatus.

\section{Conclusions}

From an evolutionary viewpoint, the variations observed in C. lunatus colony, conidia size, conidia colour, conidia texture, and the presence or absence of stromata should be regarded as prominent acquired adaptational traits. These characteristic traits were not consistent between the five strains causing foliar necrosis of potato but provided indicators for generic circumscription. Phenotypic intraspecific variations can obscure placement of Cochliobolus species and make correlation to phylogeny difficult. As shown, C. lunatus have considerable ecological and economic importance being a highly successful colonizer in monocots, dicots, vertebrates, and invertebrates. On this basis, the purpose as a biocontrol agent is overshadowed by its virulent and indiscriminate destructive potential in the ecosystem. For this reason, we suggest that the use of $C$. lunatus as mycoherbicide should be stopped.

\section{Conflict of Interests}

The authors declare there is no conflict of interests.

\section{Acknowledgments}

This research was jointly supported by the Academy of Sciences for Developing World (TWAS), Trieste, Italy, and the Department of Biotechnology, Government of India (Program no. 3240223450). 


\section{References}

[1] A. J. Ullstrup, "The impact of the southern corn leaf blight epidemics of 1970-71," Annual of Review of Phytopathology, vol. 10, pp. 37-50, 1972.

[2] J. Chen, H. H. Yan, Z. G. Gao, C. S. Xue, and J. H. Zhuang, "Identification techniques for physiological differentiation of Curvularia lunata in maize," ACTA Phytopathologica Sinica, vol. 33, no. 2, pp. 121-125, 2003.

[3] H. H. Yan, J. Chen, Z. G. Gao, S. C. Xia, and R. Q. Zhang, "The heredity and variation of the interaction between Curvularia lunata and plant," Journal of Maize Science, vol. 13, no. 2, pp. 119-120, 2005.

[4] S. Y. Padmanabhan, “The great Bengal famine," Annual Review of Phytopathology, vol. 11, pp. 11-26, 1973.

[5] R. P. Scheffer, The Nature of Disease in Plants, Cambridge University Press, 1997.

[6] D. S. Manamgoda, L. Cai, A. H. Bahkali, E. Chukeatirote, and K. D. Hyde, "Cochliobolus: an overview and current status of species," Fungal Diversity, vol. 51, pp. 3-42, 2011.

[7] R. R. Nelson and F. A. Haasis, "Cochliobolus lunatus," Mycologia, vol. 56, no. 2, p. 316, 1964.

[8] P. S. Bisen, "Production of toxin metabolites by Curvularia lunata and its role in leaf spot disease of bean," Acta Botanica Indica, vol. 11, no. 3, pp. 235-238, 1983.

[9] H. Tsukamoto, M. Tsuda, M. Gohbara, and T. Fujimori, "Effect of water management on mycoherbicidal activity of Exserohilum monoceras against Echinochloa oryzicola," Annals of the Phytopathological Society of Japan, vol. 64, no. 6, pp. 526-531, 1998.

[10] S. W. Huang, L. Q. Yu, G. F. Duan, and K. Luo, "Study on barnyard grass (Echinochloa crus-galli) control by Helminthosporium gramineum and Exserohilum monoceras," Acta Agronomica Academiae Scientiarum Hungaricae, vol. 35, no. 1, pp. 66-72, 2005.

[11] M. R. S. Motlagh, "Evaluation of Curvularia lunata as an biological control agent in major weeds of rice paddies," Life Science Journal, vol. 8, no. 2, pp. 81-91, 2011.

[12] Z. B. Zhang, N. R. Burgos, J. P. Zhang, and L. Q. Yu, "Biological control agent for rice weeds from protoplast fusion between Curvularia lunata and Helminthosporium gramineum," Weed Science, vol. 55, no. 6, pp. 599-605, 2007.

[13] G. Jyothi, K. R. N. Reddy, R. N. Reddy, and A. R. Podile, "Exploration of suitable solid media for mass multiplication of Cochliobolus lunatus and Alternaria alternata used as mycoherbicide for weed management (barnyard grass) in rice," Journal of Experimental Biolology and Agricultural Sciences, vol. 1, no. 4, pp. 281-284, 2013.

[14] A. Sivanesan, Graminicolous Species of Bipolaris, Curvularia, Drechslera, Exerohilum and Their Telemorphs, CAB International, 1987.

[15] M. L. Berbee, M. Pirseyedi, and S. Hubbard, "Cochliobolus phylogenetics and the origin of known, highly virulent pathogens, inferred from ITS and glyceraldehyde-3-phosphate dehydrogenase gene sequences," Mycologia, vol. 91, no. 6, pp. 964-977, 1999.

[16] I. Ahmad, S. Iram, and J. Cullum, "Genetic variability and aggressiveness in Curvularia lunata associated with rice-wheat cropping areas of Pakistan," Pakistan Journal of Botany, vol. 38, no. 2, pp. 475-485, 2006.
[17] W. Msikita, J. S. Yaninek, M. Ahounou, H. Baimey, and R. Fagbemissi, "First report of Curvularia lunata associated with stem disease of cassava," Plant Disease, vol. 81, no. 1, p. 112, 1997.

[18] E. E. John and K. P. Louis, "Seed mycoflora for grain mold from natural infection in sorghum germplasm grown at Isabela, Puerto Rico and their association with kernel weight and germination," Plant Pathology Journal, vol. 5, no. 1, pp. 106-112, 2006.

[19] V. S. Verma, R. D. Brahmana, and V. S. Gupta, "First Report of Curvularia lunata causing root rot of strawberry in India," Plant Disease, vol. 94, no. 4, pp. 477-477, 2010.

[20] B. Louis, P. Roy, S. D. Waikhom, and N. C. Talukdar, "Report of foliar necrosis of potato caused by Cochliobolus lunatus in India," Africa Journal Biotechnology, vol. 12, no. 8, pp. 833-835, 2013.

[21] M. Kimura, "A simple method for estimating evolutionary rates of base substitutions through comparative studies of nucleotide sequences," Journal of Molecular Evolution, vol. 16, no. 2, pp. 111120,1980

[22] K. Tamura and M. Nei, "Estimation of the number of nucleotide substitutions in the control region of mitochondrial DNA in humans and chimpanzees," Molecular Biology and Evolution, vol. 10, no. 3, pp. 512-526, 1993.

[23] T. J. White, T. D. Bruns, S. B. Lee, and J. W. Taylor, "Amplification and sequencing of fungal ribosomal RNA genes for phylogenetics," in PCR-Protocols and Applications. A Laboratory Manual, N. Innis, D. Gelfand, J. Sninsky, and T. C. White, Eds., pp. 315322, Academic Press, New York, NY, USA, 1990.

[24] R. C. Edgar, "MUSCLE: multiple sequence alignment with high accuracy and high throughput," Nucleic Acids Research, vol. 32, no. 5, pp. 1792-1797, 2004.

[25] K. Tamura, G. Stecher, D. Peterson, A. Filipski, and S. Kumar, "MEGA6: molecular evolutionary genetics analysis version 6 . 0," Molecular Biology and Evolution, vol. 30, no. 1, pp. 2725-2729, 2014.

[26] L. G. Barrett, P. H. Thrall, P. N. Dodds et al., "Diversity and evolution of effector loci in natural populations of the plant pathogen melampsora lini," Molecular Biology and Evolution, vol. 26, no. 11, pp. 2499-2513, 2009.

[27] J. W. Kirchner and B. A. Roy, "Evolutionary implications of host-pathogen specificity: fitness consequences of pathogen virulence traits," Evolutionary Ecology Research, vol. 4, no. 1, pp. 27-48, 2002.

[28] N. A. Amusa, A. A. Adegbite, and M. O. Oladapo, "Investigations into the role of weeds, soil and plant debris in the epidemiology of foliar fungal diseases of yam in western Nigeria," International Journal of Botany, vol. 1, no. 2, pp. 111115, 2005.

[29] M. Braithwaite, C. F. Hill, S. Ganev, J. M. Pay, H. G. Pearson, and B. J. R. Alexander, "A survey of sub-tropical nursery plants for fungal diseases in northland," New Zealand Plant Protection, vol. 59, no. 1, pp. 132-136, 2006.

[30] N. Nishi, T. Muta, M. Nakamura, M. Takemure, and T. Tsukiboshi, "Leaf spot of Saccharum officinarum caused by Curvularia lunata," Japanese Journal of Phytopathology, vol. 74, no. 1, pp. 118-120, 2008.

[31] A. R. Marvin and G. T. Naomi, "Diseases of passion fruit (Passiflora edulis $\mathrm{f}$. flavicarpa Deg.) in three municipalities of North and South Cotabato, Philippines," USM R\&D Journal, vol. 17, no. 2, pp. 123-129, 2009.

[32] H. Azhar, A. A. Safdar, G. M. Sahi, Q. Abbas, and Imran, "Seed borne fungal pathogens associated with pearl millet 
(Pennisetum typhoides) and their impact on seed germination," Pakistan Journal Phytopathology, vol. 21, no. 1, pp. 55-60, 2009.

[33] M. D. Cvetomir, "New records of fungi-like organisms and slime moulds from Europe and Asia," Mycologia Balcanica, vol. 8, no. 1, pp. 173-175, 2011.

[34] R. K. Pandey, P. K. Gupta, M. Srivastava, S. R. Singh, and G. Robin, "First report of brown leaf spot disease caused by Curvularia lunata infecting Indian spinach or poi (Basella rubra)," Indian Phytopathology, vol. 64, no. 2, p. 207, 2011.

[35] K. Selima, C. Urgar, C. Manoranjan, S. Ojha, and N. C. Chatterjee, "Biochemical defense against die-back disease of a traditional medicinal plant Mimusops elengi linn," European Journal of Medicinal Plants, vol. 1, no. 4, pp. 40-49, 2011.

[36] P. Sharma, N. Singh, and O. P. Verma, "First report of curvularia lunata associated with leaf spot of Amaranthus spinosus," Asian Journal of Plant Pathology, vol. 5, no. 2, pp. 100-101, 2011.

[37] A. Saleem, A. H. M. El-Said, T. A. Maghraby, and A. Hamid, "Pathogenicity and pectinase activity of some facultative mycoparasites isolated from Vicia faba diseased leaves in relation to photosynthetic pigments of plant," Journal Plant Pathology and Microbiology, vol. 3, no. 6, p. 141, 2012.

[38] N. M. Ghangaonkar, "Incidence of mycoflora on garlic (Allium sativum L.) bulbs," International Research Journal of Biological Sciences, vol. 2, no. 7, pp. 64-66, 2013.

[39] V. Pratibha, S. Shailu, and S. Ranjana, "Seven species of Curvularia isolated from three lakes of Bhopal," Advances in Life Science and Technology, vol. 8, pp. 13-15, 2013.

[40] A. Mukherjee, A. Bandhyopadhyay, and S. Dutta, "New report of leaf spot disease of clerodendrum indicum caused by Curvularia lunata," International Journal of Pharma and Bio Sciences, vol. 4, no. 3, pp. B808-B812, 2013.

[41] S. Gao, T. Liu, Y. Li, Q. Wu, K. Fu, and J. Chen, "Understanding resistant germplasm-induced virulence variation through analysis of proteomics and suppression subtractive hybridization in a maize pathogen Curvularia lunata," Proteomics, vol.12, no. 2324, pp. 3524-3535, 2012.

[42] S. Xu, J. Chen, L. Liu, X. Wang, X. Huang, and Y. Zhai, "Proteomics associated with virulence differentiation of Curvularia lunata in maize in China," Journal of Integrative Plant Biology, vol. 49, no. 4, pp. 487-496, 2007.

[43] B. Louis, S. D. Waikhom, P. Roy et al., "Secretome weaponries of Cochliobolus lunatus interacting with potato leaf at different temperature regimes reveal a CL[xxxx]LHM-motif", $B M C$ Genomics, vol. 15, article 213, 2014.

[44] J. J. Muchovej and H. B. Couch, "Colonization of bent-grass turf by Curvularia lunata after leaf clipping and heat stress," Plant Disease, vol. 71, pp. 873-875, 1987.

[45] P. Van Baarlen, A. Van Belkum, R. C. Summerbell, P. W. Crous, and B. P. H. J. Thomma, "Molecular mechanisms of pathogenicity: how do pathogenic microorganisms develop cross-kingdom host jumps?" FEMS Microbiology Reviews, vol. 31, no. 3, pp. 239-277, 2007.

[46] R. M. Kepler, G.-H. Sung, Y. Harada et al., "Host jumping onto close relatives and across kingdoms by Tyrannicordyceps (Clavicipitaceae) gen. nov. and Ustilaginoidea (Clavicipitaceae)," American Journal of Botany, vol. 99, no. 3, pp. 552-561, 2012.

[47] J. D. Nosanchuk and A. Casadevall, "Impact of melanin on microbial virulence and clinical resistance to antimicrobial compounds," Antimicrobial Agents and Chemotherapy, vol. 50, no. 11, pp. 3519-3528, 2006.
[48] B. Louis, S. D. Waikhom, M. S. Wakambam, N. C. Talukdar, and R. Pranab, "Diversity of ascomycetes at the potato interface: new devastating fungal pathogens posing threat to potato farming," Plant Pathology Journal, vol. 13, no. 1, pp. 18-27, 2014.

[49] J. Goa, T. Liu, and J. Chen, "Insertional mutagenesis and cloning of the gene required for the biosynthesis of the non-host specific toxin in Cochliobolus lunatus that causes maize leaf spot," Phytopathology, vol. 104, no. 4, pp. 332-339, 2014. 

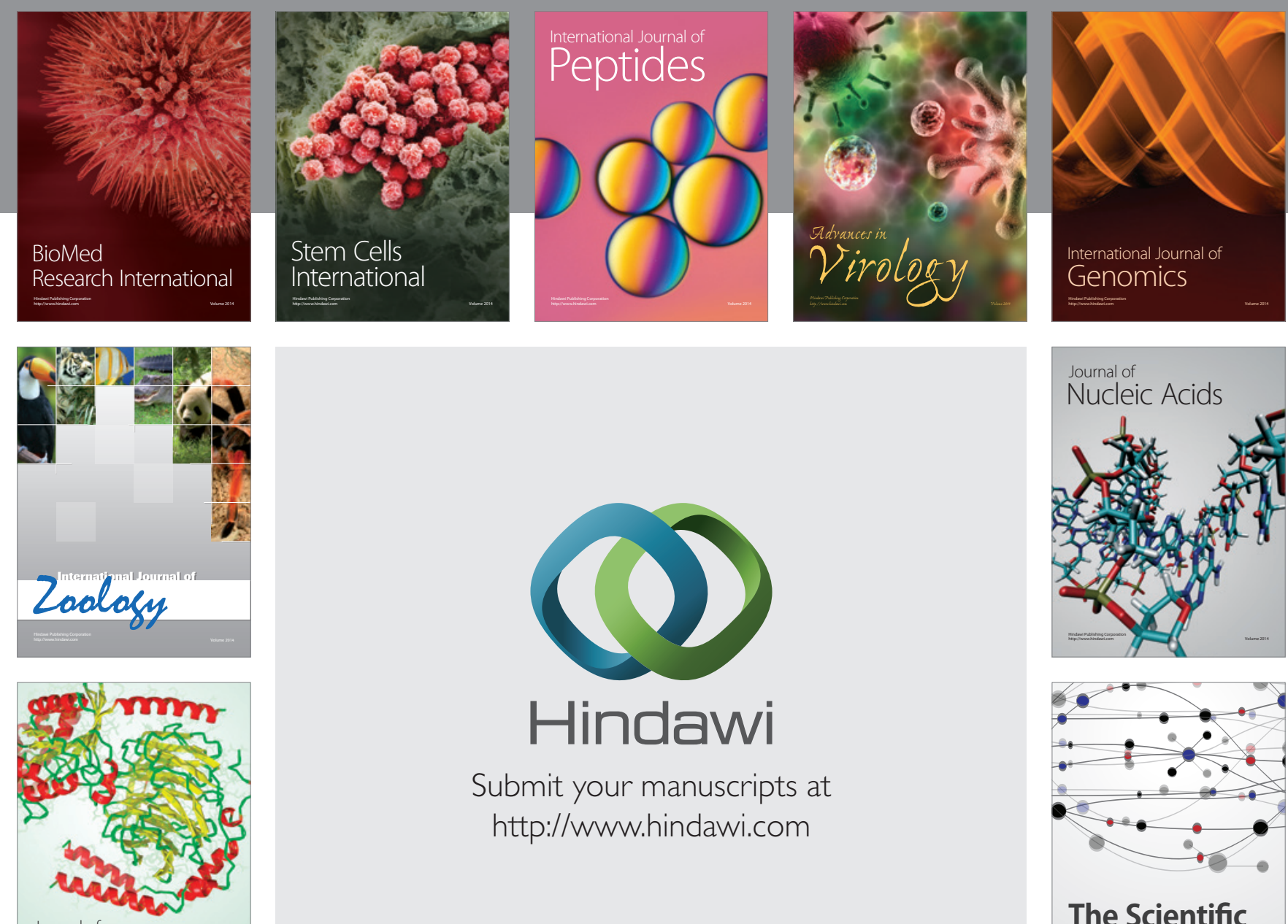

Submit your manuscripts at

http://www.hindawi.com

Journal of
Signal Transduction
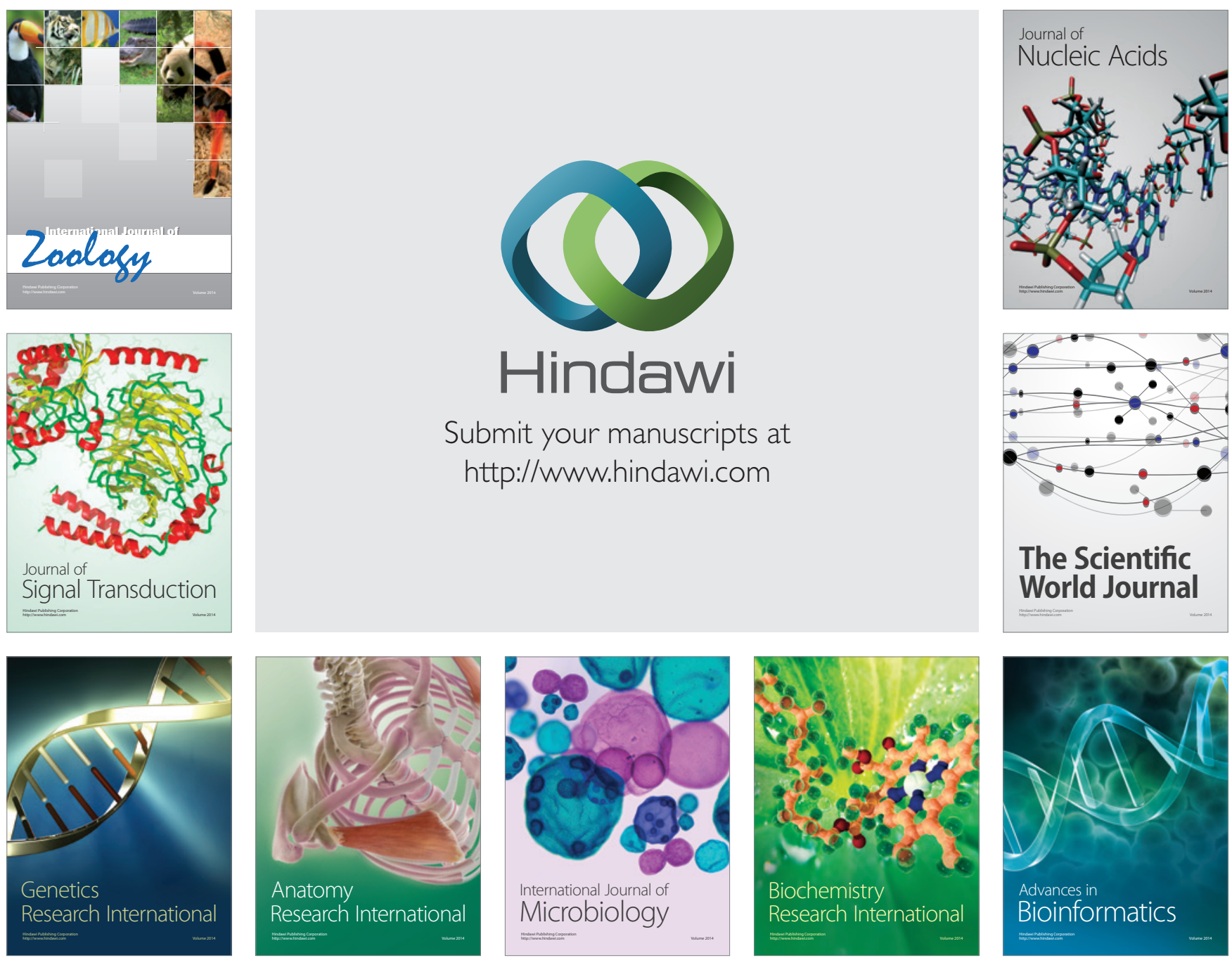

The Scientific World Journal
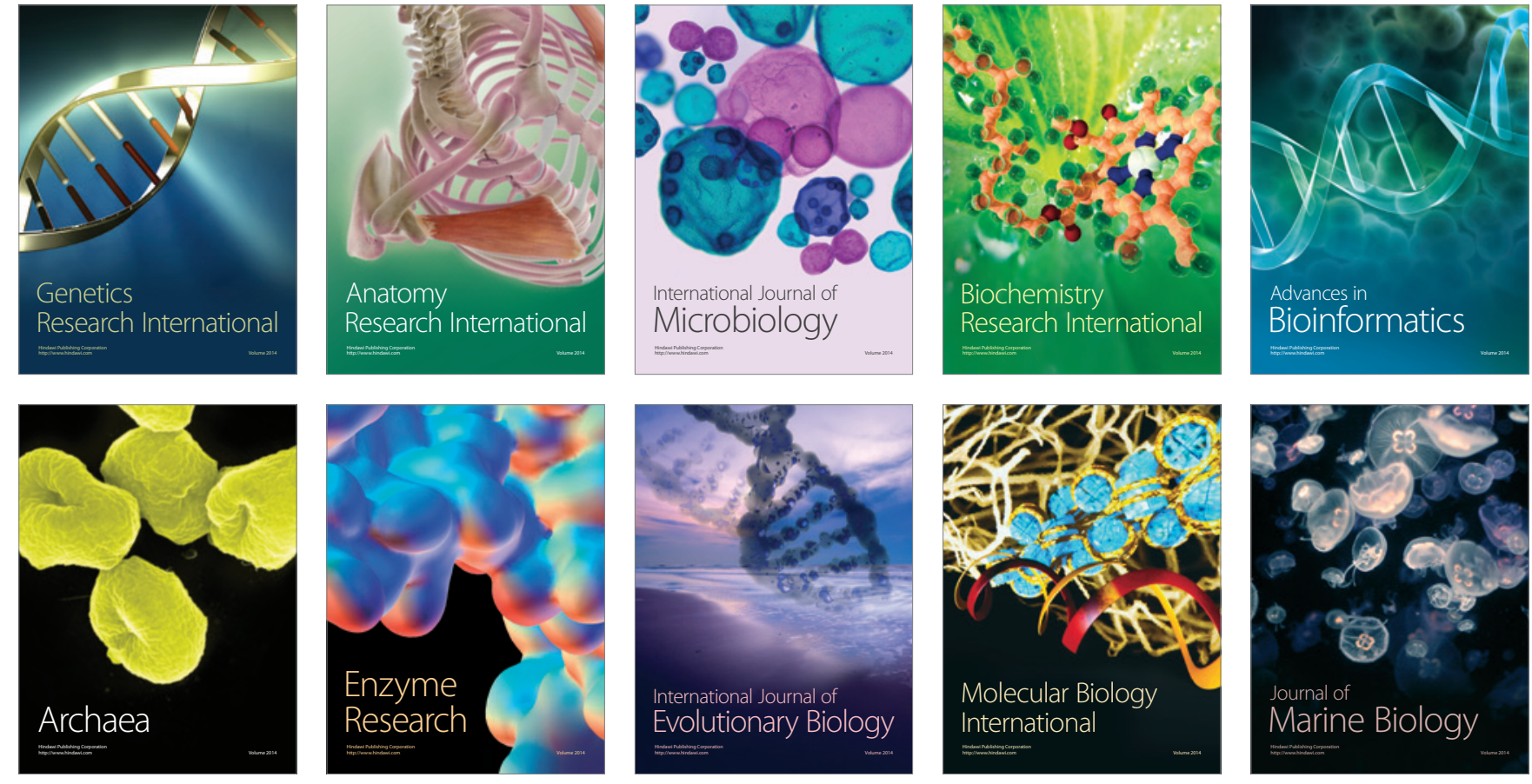